\title{
الأمن النفسي وتأثيره على الأبناء
}

\author{
إعراد \\ الباحث/محمد شفيق محمود خطاب
}

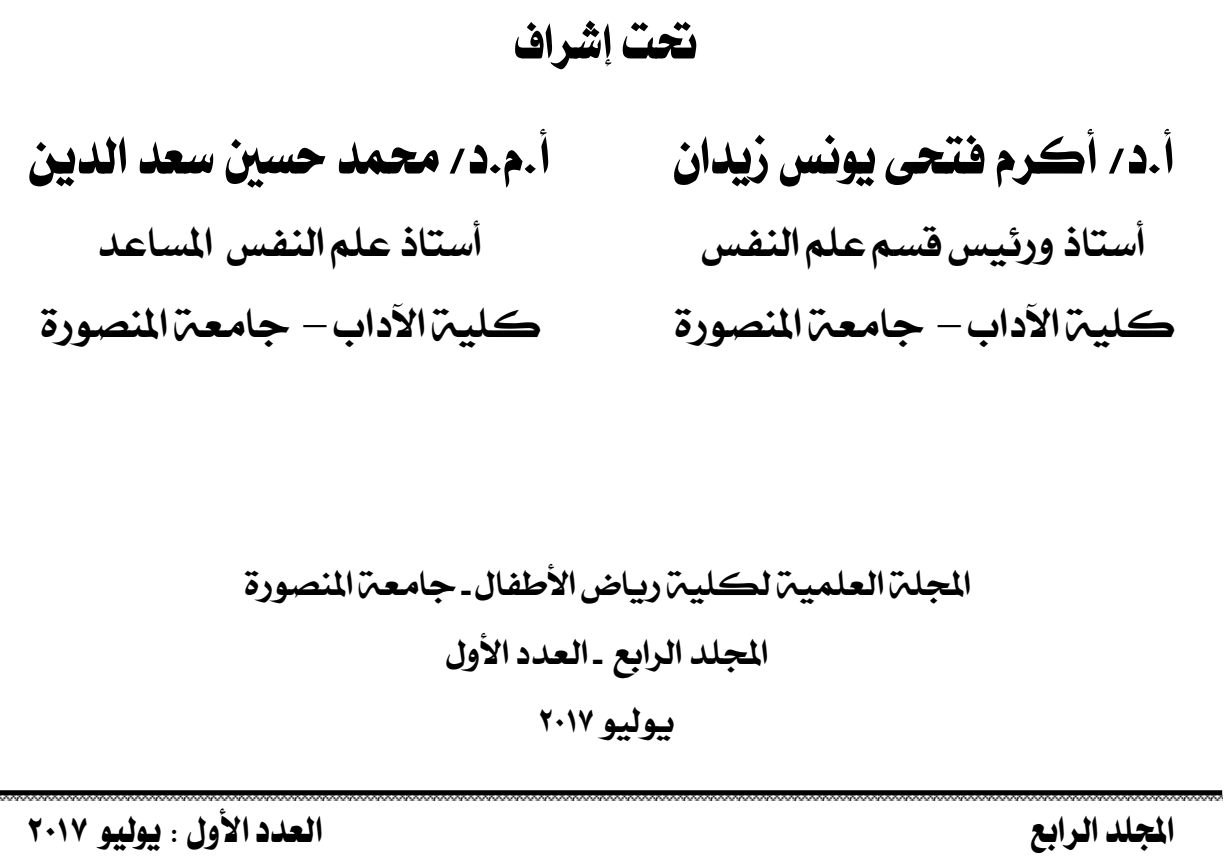




\section{الأمن النفسي وتأثيره على الأبناء}

* محمد شفيق محمود خطاب

الأمن التفسي

يعتبر الأمن مطلب ضروري لحياة الإنسان ، فلا طعم للحياة بدون الأمــن

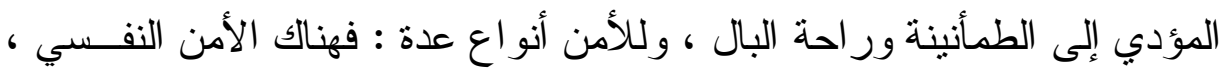

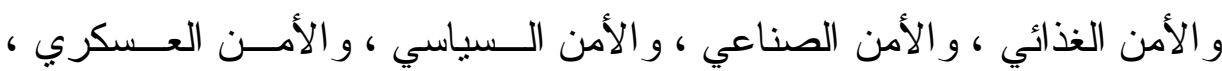
و غير ها، ولكن الأمن النفسي للفرد من أهمها و أكثر ها التصاقا بكل فرد بعينه ، وقد ظل الإنسان منذ وجد على هذه الأرض يبحث عن أمنه النفسي من خلال سعيه إلى الى تحقيق حاجاته الضرورية وتقوية علاقته بأخيه الإنسان حتى يأمن جانبه ويينـي ماني

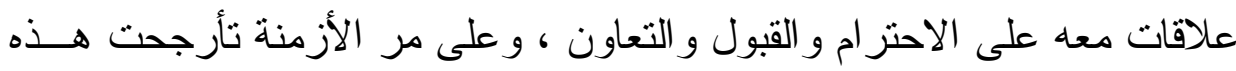

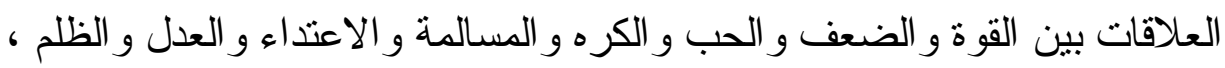

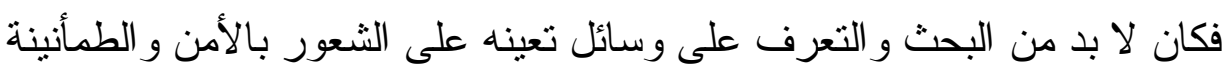

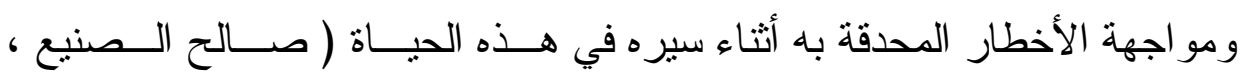
. (r): : $199 \mu$

(1) مفهوم الأمن النفسي فيما يلى عرضاً لمُختلف آر اء الباحثين حول مفهوم الأمن النفسى : (أ) التعريف اللغوى : الأمن فى اللغة هو " أمن ، أمناً ، و أماناً ، و أمانة ، ومناً ، و إمناً ، و إمنةًا،

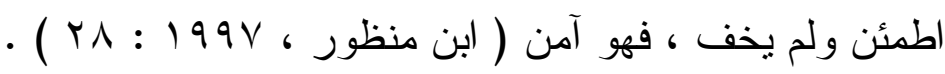
" باحث * 
و الأمنُ ، و الآمنُ ضد الخوف ، فهو آمنٌ وأمين ، أمنَ الرجل اطمأن ولم

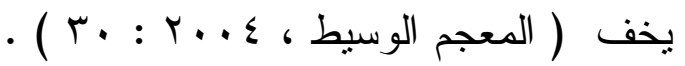

$$
\begin{aligned}
& \text { (ب) التعريف الإصطلاحى : }
\end{aligned}
$$

تعددت تعريفات الباحثين حول مفهوم الأمن النفسى ، وفيما يلى عرضـــاً

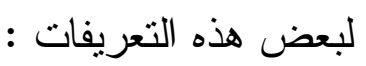

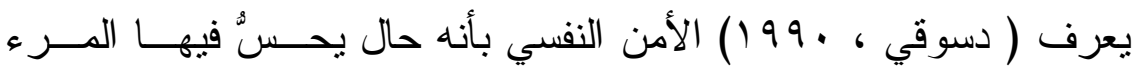

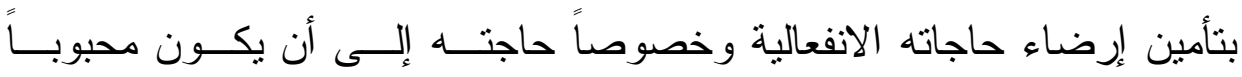

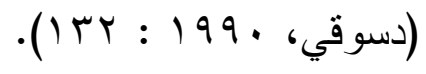

كما يعرف (الحفني ، ـ991) أن الأمن النفسي ينبع من شعور الفرد بأنه يستطيع الإبقاء على علاقات مشبعة ومتزنة مع الناس ذوى الأن الأهمنية الانفعالية في

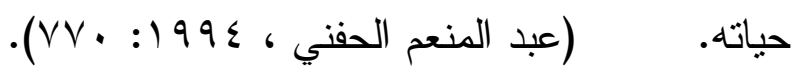

ويذكر كل من (عبد الحميد ، وكفافي ، 1990 (أن الأمن النفـسي يعنـي

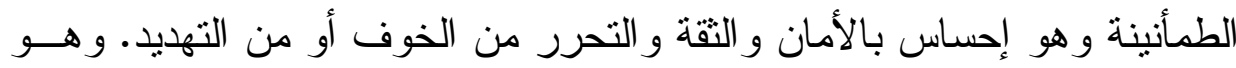

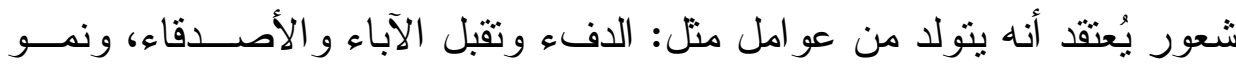

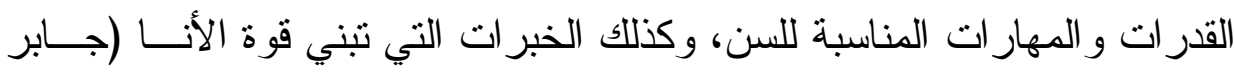
عبد الحميد و علاء الدين كفافي ، 990 (1).

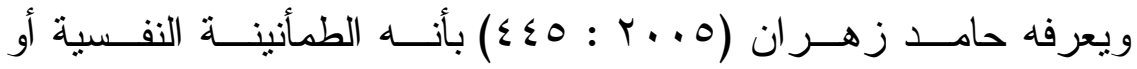

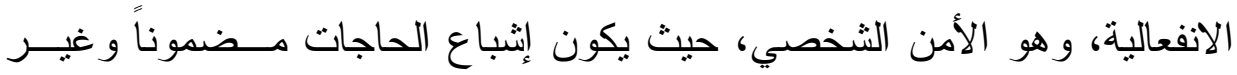

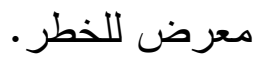

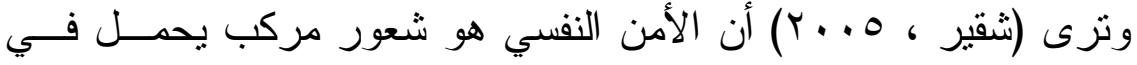

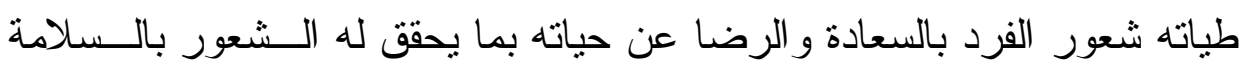


و الاطمئنان، و أنه محبوب ومتقبل من الآخرين بما يمكنه من تحقيق قدر أكبر من

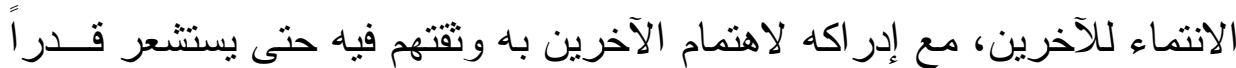

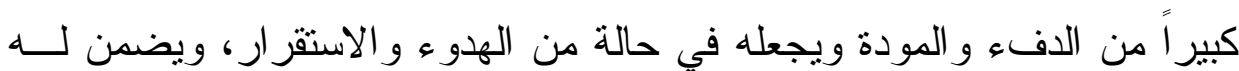

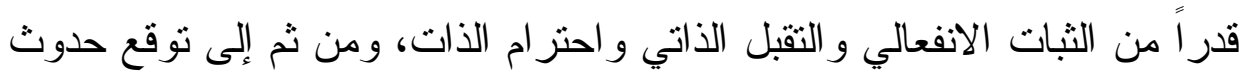

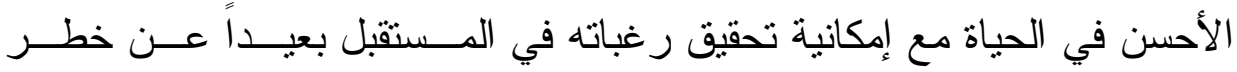

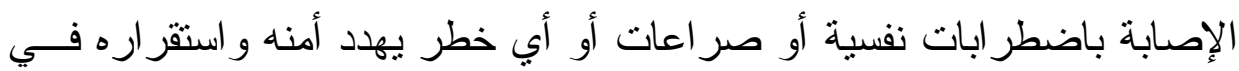

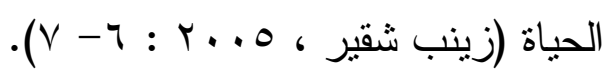

ويذهب فيننيمان (Fenniman, 2010) إلى أن الأمن النفسي يقـصد بــــ شعور الفرد بالقدرة على ارنياد المخاطر بدون الخوف من العو اقــب و النتــائج

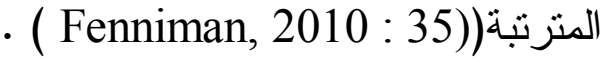

ويشير ميلياد (Mulyadi, 2010) إلى أن الأمن النفـسي يعنـي شـــور الفرد بالر احة و التقة بالنفس، و القدرة على تقدير ذاته وتحقيق قدر اتـهـ وتحسـسين

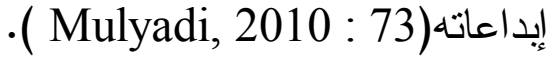
وتذكر (بسيوني ، و الصبان ، 11 بـ) أن الأمن النفسي هو حالة نفـسية

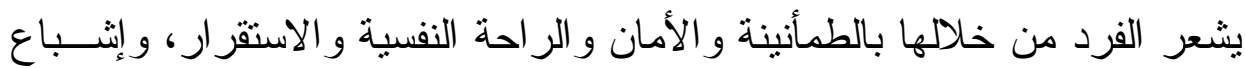

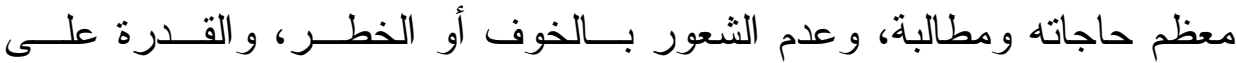
المو اجهة دون حدوث أي اضطر اب أو خلل.

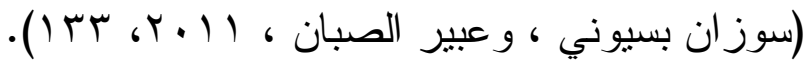
ويرى نافا و التانانتي (Nafaa\& Eltanahi,2011) أن الثعور بــالأمن

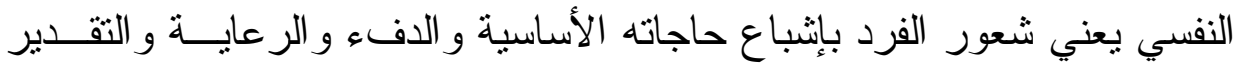
والثقة (104) : Nafaa\& Eltanahi,2011). 
ويعرفه الدومي (Al-Domi, 2012) بأنه شعور الفرد بالسلام الــداخلي

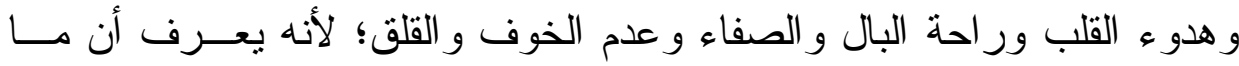

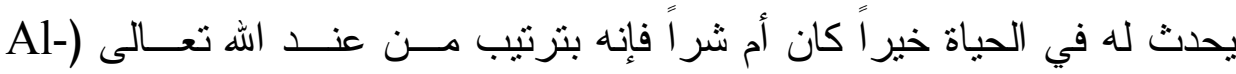

.(Domi, 2012 : 53

ويذهب ريبين، ويس وكول (Rubin, Weiss \& Coll, 2013) إلـى

أن الأمن النفسي يعني شعور الفرد بالإيجابية تجاه حياته ، و الكفـــاءة فـي إدارة

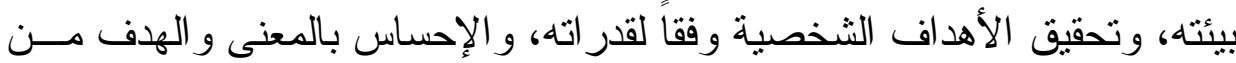
الحياة، و الاتجاه الإيجابي نحو ذاته وتقبلها.

.( Rubin, Weiss \& Coll, $2013: 420)$

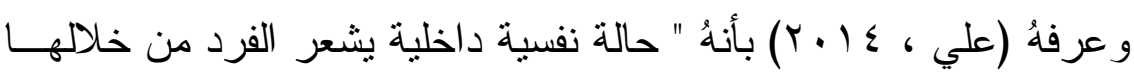

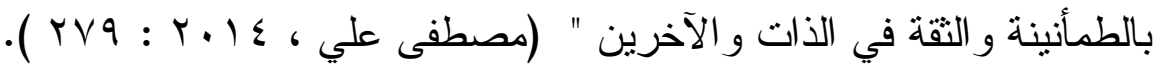

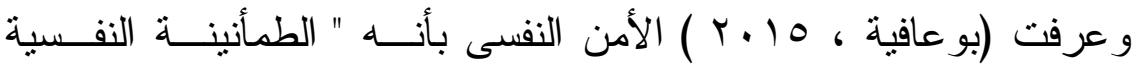

و الانفعالية ، و الثعور بالهدوء ، و السكينة ، وسلام الروح " (نبيلــة بوعافيــة ،

. ( $9 \leq: 4 \cdot 10$

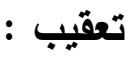

من العرض السابق للتعريفات التى تتاولت الأمن النفسى يتضح للباحــث

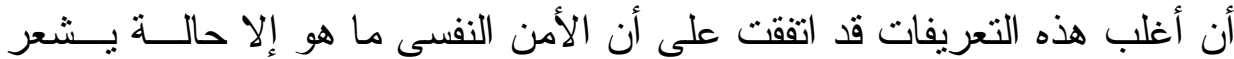

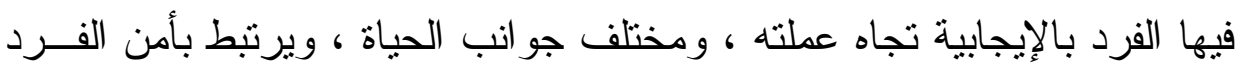
الاجتماعى وصحته النفسية ، ويرى الباحث أن الأمن النفسى حالة نفسية عقليـــة

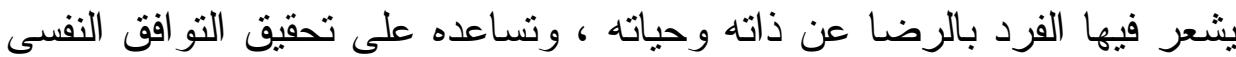

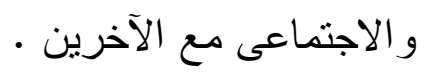


يشير (دسوقي ، .991) إلى أن الأمن النفسي اتجاه مركب مــن تملــك

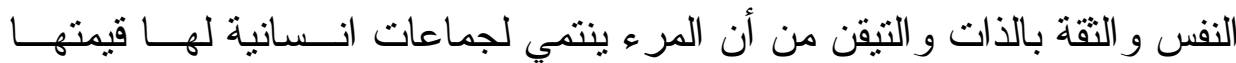

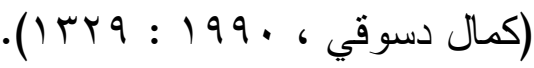

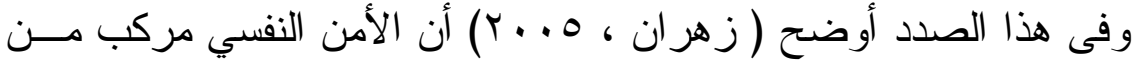

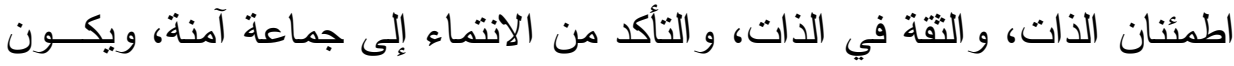
الثخصي الآمن نفسياً في حالة توازن أو نو القن أمني.

وفي ضوء ما سبق يتضح أن الأمن النفسي يتضمن المكونات الآتية : (1)(اطمئنان الذات: هو شــور الفـرد بالاطمئنــان، والأمــن، و الهـدوء، و الاستقرار، و السلامة، وعدم الخوف - من قبل الجماعات الإنسانية التي

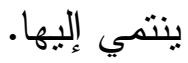

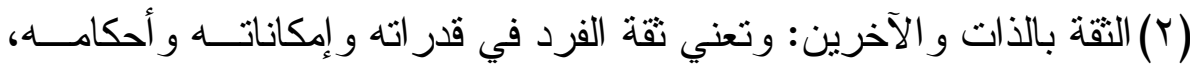

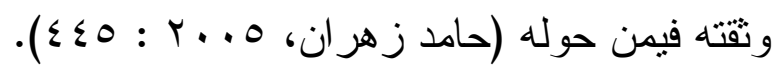

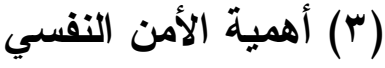
إن الأمن النفسي إذا توفر لجميع الأفر اد فسيقوم كل فرد بأداء عمله بالثكل

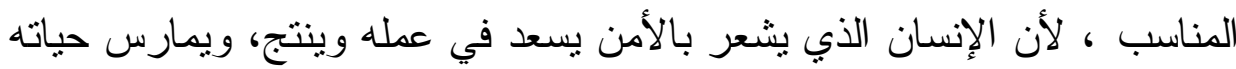
الطبيعية ، كما وتختلف الحاجة إلى الأمن وخدماته من شخص إلى أخر ، بالآنسبة للفرد و المجتمع و الدولة ، فبالنسبة للفرد فان خدمات الأمن هي الضمان لحريته ،

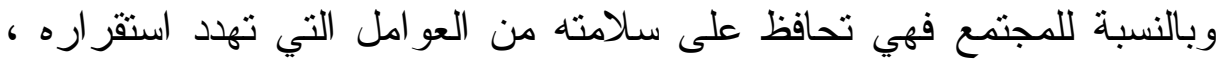

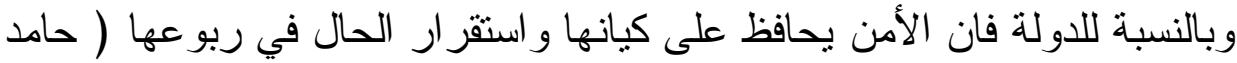

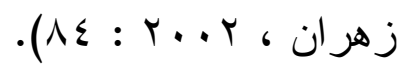




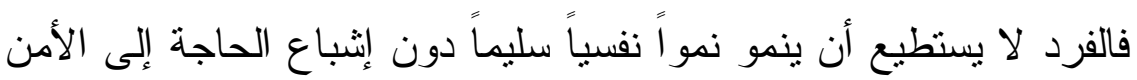

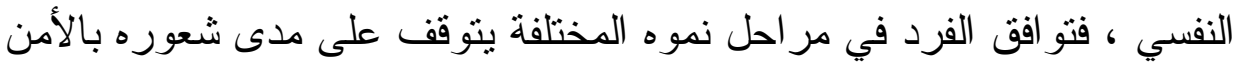

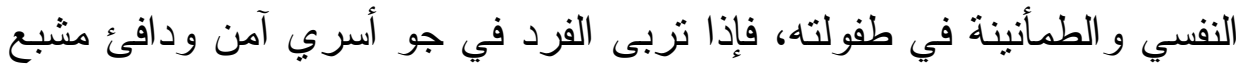

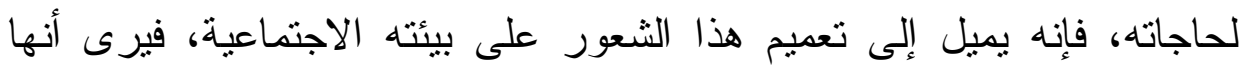
مشبعة لحاجاته ويرى في الناس الخير والحب فيتعاون ويتعامل بصدق، ويتسم بالتفاؤل و الرضا مما يجعله يحظى بتقدير الآخرين، فينعكس ذلائك على تقبله

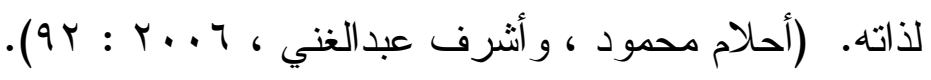

و الأمن النفسي أحد الحاجات المهمة للشخصية الإنسانية :حيث تمتن

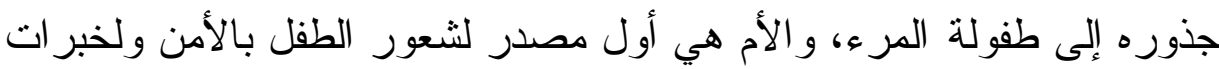

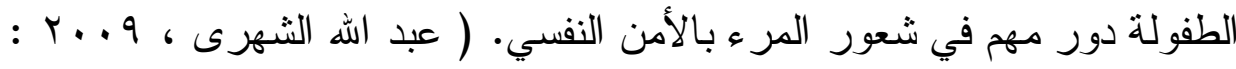
$\cdot(r \wedge$ ويثير الدومي (Al - Domi, 2012) إلى أن الإحساس بالراحة و الهدوء ور احة البال تأتي في مصاف الأولويات الأولى للإنسان، و إن كل فرد الني يحاول الوصول إليها، ولكن بعض الناس يعتقد أن الوصول للسعادة عن طريق

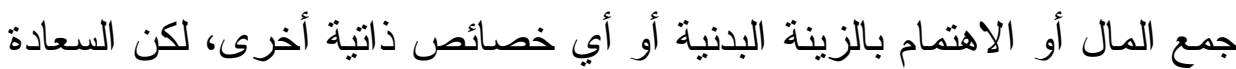

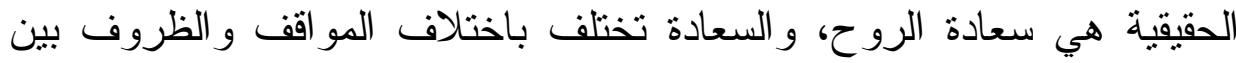
الفقر و الغني و الصحة و المرض، وكذلك حياة القلب و التي لا يصل إليها الإنسان

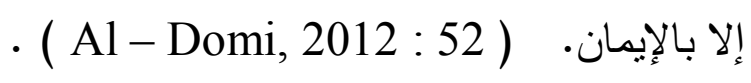

( ) إلعوامل المؤثرة في الأمن النفسي إن أهم العو امل و المتغير ات المؤثرة في الأمن النفسي هى : (أ) الإيمان باله و التصسك بتعاليم الدين: حيث يجعل الإنسان في مـــأمن مـن

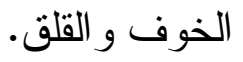


(ب) التتشئة الاجتماعية: فأساليب التتشئة الاجتماعية السوية مثـلـل التـسامح و النقبل و التعاون و الاحتر ام تتمي الإحساس بالأمن النفسي.

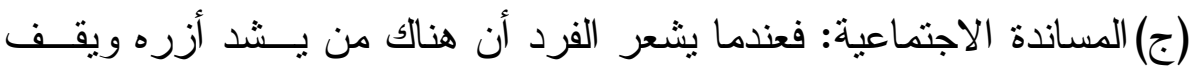

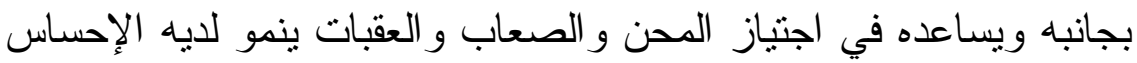

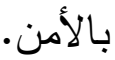

(د) المرونة الفكرية: يرتبط الإحساس بالأمن إيجاباً بالتفكير و المرونة الفكرية وذللك في إطار المبادئ و القو انين وما يقره المجتمع و الدين. (ه) الصحة الجسمية: إن الصحة الجسمية ترنبط إيجاباً بالأمن حيث الإحساس

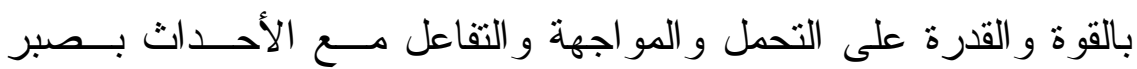

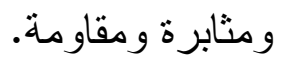

(و) الصحة النفسية: نقوي الصحة النفسية و التمتع بها مع الإحسـساس بـالأمن

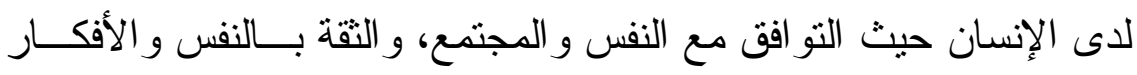

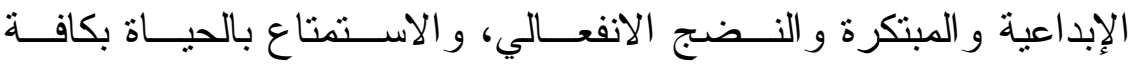

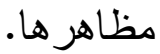

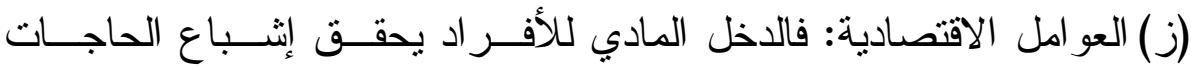

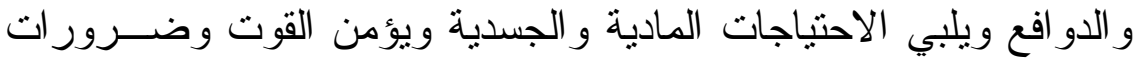

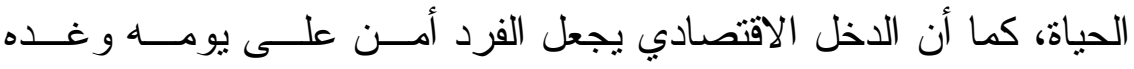
وحاضره ومستقبله ومسنقبل أو لاده.

(ح) الاستقرار الأسري والاجتماعي: فالاستقر ار الأسري و الاجتماعي يجــل

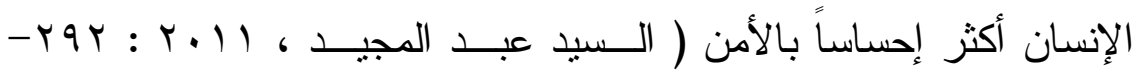
.$(490$ 


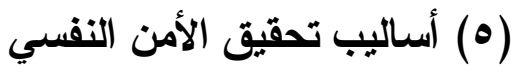

لتحقيق الأمن النفسي ، يلجأ الفرد الى ما يسمى" عمليات الأمن النفـسي "

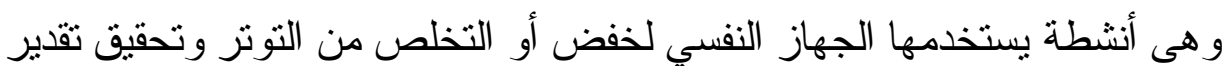
ألذات و الثعور بالأمان، ويجد الفرد أمنه النفسي في انضمامه الى جماعة تشعره

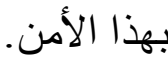

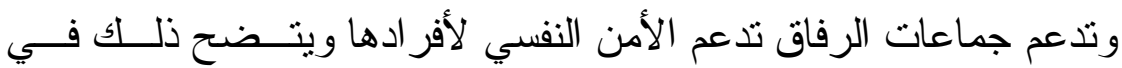

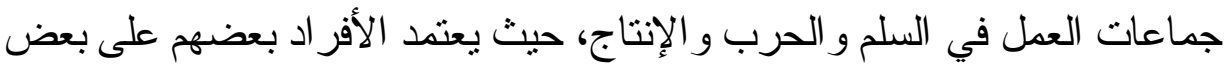

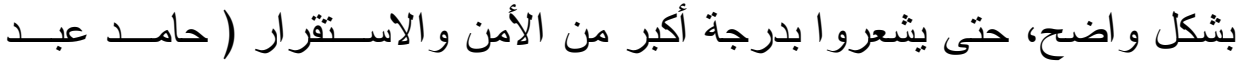

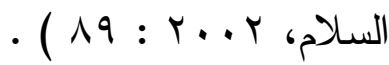

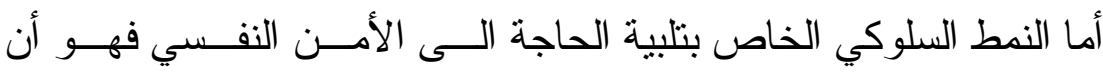
الثخصية تكون في حاجة الى التحرر من الخوف أيا كان مصدره، كما أنه يكون

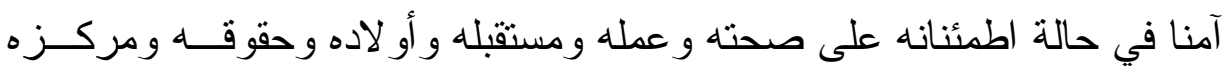

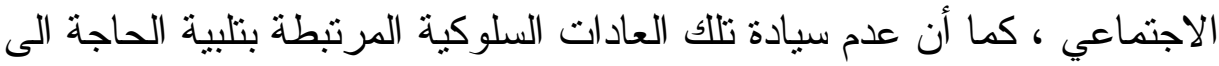
الأمن النفسي" يتعلق بعدم مر اعاة الابتعاد عن التهديد من قبل القائمين على العمل

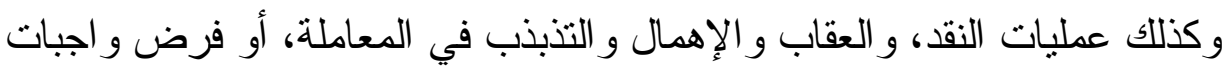

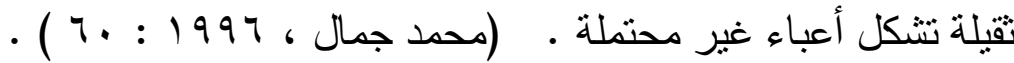
وكما هو معلوم فالإنسان يولد مزودًا بمجموعة من الدو افع منها الفطرية أو

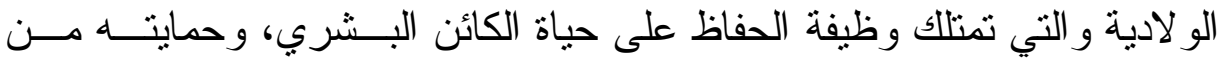
الأخطار ومن هذه الدو افع على سبيل المثال( دافع الجوع و العطش و الدافع الجنسي ودافع الحاجة الى الهو اء و الحفاظ على حرارة الجسد و التخلص من التعب وتجنب

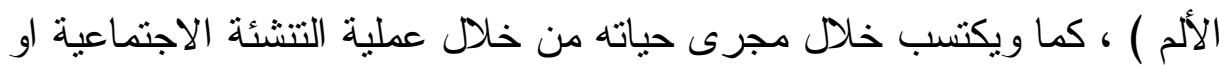
عن طريق الملاحظة مجموعة من الدو افع تطلق عليها تسمية الــدو افع الثانويــة، 
وهي دو افع يختص بها الإنسان دون غيره من الكائنات الحية ومن بينها الحاجــة

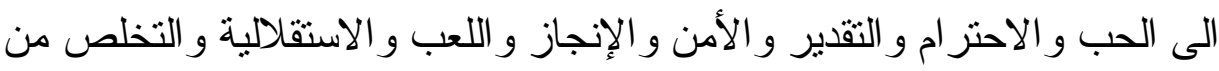

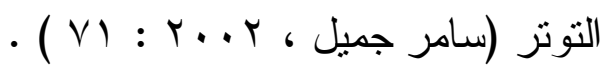

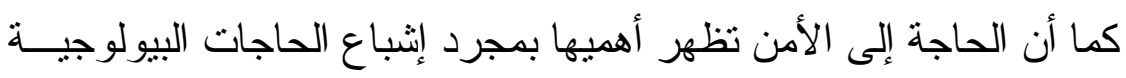

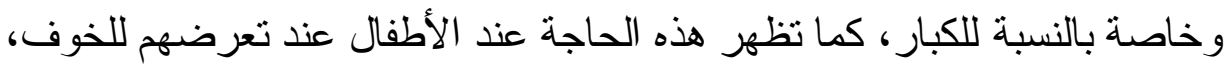

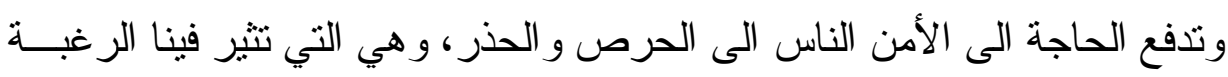

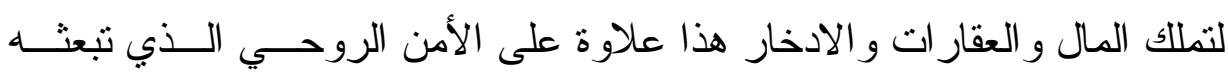

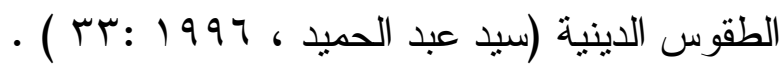

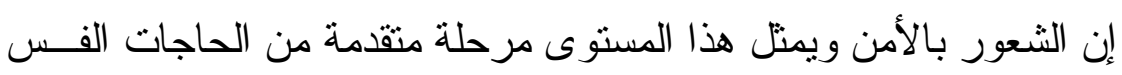

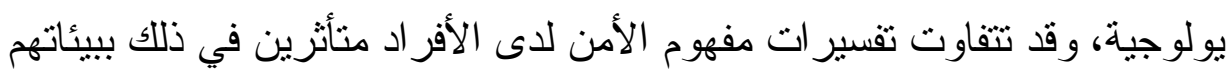

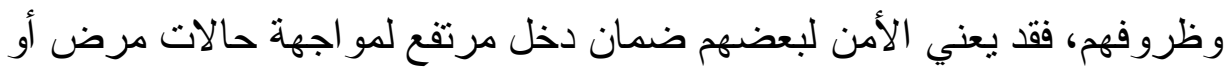

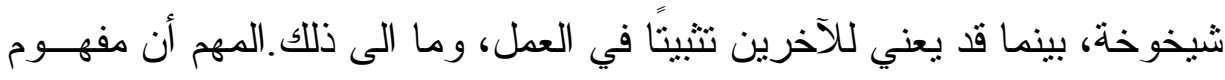

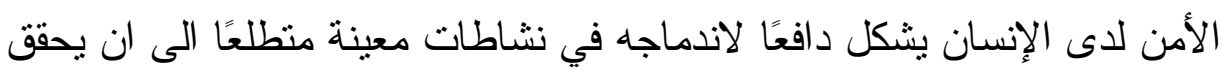

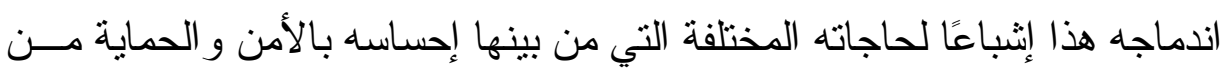

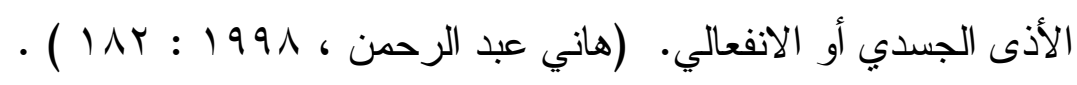

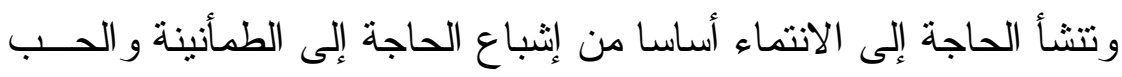

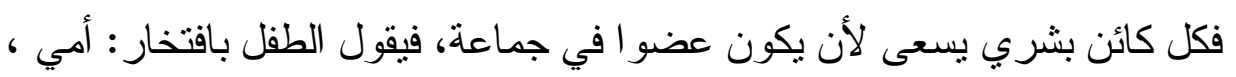

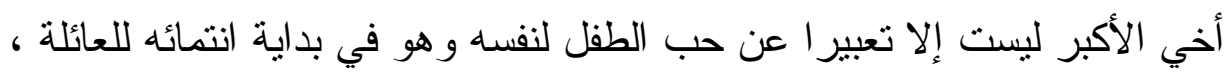

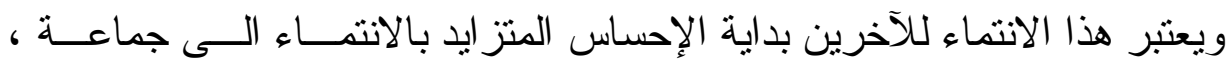

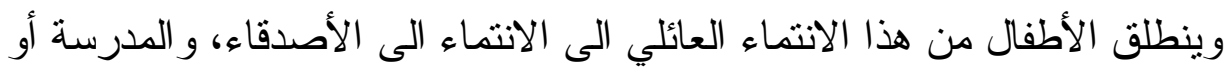

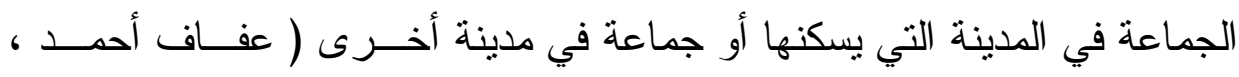
. ( r..r 
ومن أجل بناء صحة نفسية إيجابية للفرد في المجتمع الذي يتو اجد فيه يحتاج

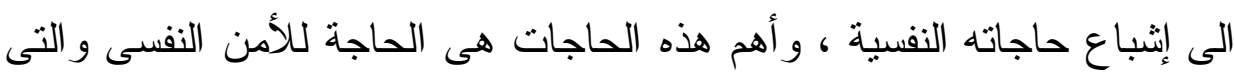

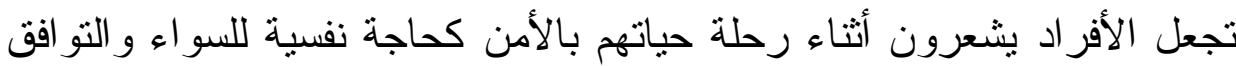

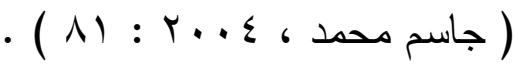

$$
\begin{aligned}
& \text { (آ) عناصر الأمن النفسي }
\end{aligned}
$$

يُشنير (الصنيع ، بو 199 ) إلى أن هناك ستة عناصر أساسية تثكل مفهوم

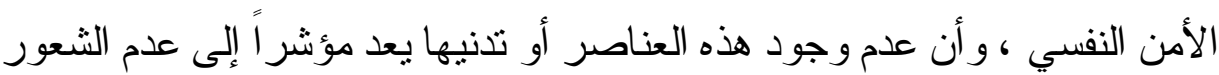

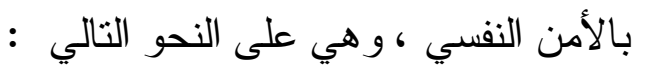

(أ) تقبل الذات : ويتمتل في نظرة الفرد لذاته نظرة ايجابية و الثعور بقيمته .

(ب) العلاقات الايجابية مع الآخرين : وتتمتل في قدرة الفرد علــى إقامسـة علاقات ايجابية مع الآخرين تتسم بالثقة و الاحتر ام المتبادل.

(ج) الاستقلالية : وتتمنل في اعتماد الفرد على نفسه وتتظيم سلوكه وتقييم ذاته من خلال معايير محددة يضعها لنفسه.

(د) السيطرة على البيئة الذانية : وتتمثل في قدرة الفرد علــى إدر الك بيئتسهـ و واستغلالها جيدا

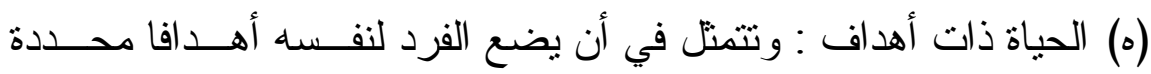

$$
\text { وو اضحة يسعى إلى تحقيقها. }
$$

(و) النطور الذاني :وتتمتل في إدر الك الفرد لقدر اته و إمكانياته و السعي نحسو

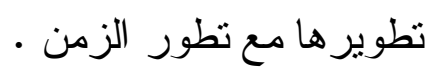

ويرى الباحث أن هذه العناصر موجودة عند أي شخص ولكن تتفاوت من شخص لآخر ، فكلما كانت هذه العناصر منو افرة بدرجة أكبر كان شعوره بالأمن 
النفسي أفضل ، وزادت فعاليته الذاتيه و واستقلاليته وطموحه وميله للانجاز

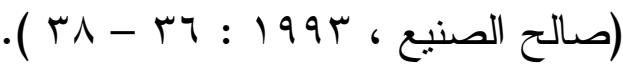

$$
\begin{aligned}
& \text { عو (V) }
\end{aligned}
$$

إن فقدان الأمن النفسي عند الإنسان يؤدي إلى الخــوف و الــشك و القـــق

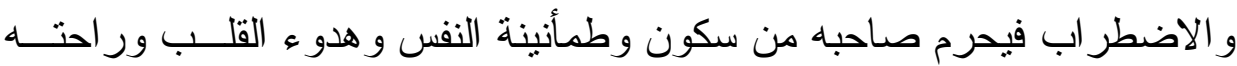

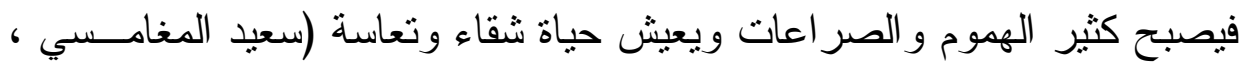
$\cdot(\varepsilon V: r \ldots V$

كما أن غياب الأمن النفسي يؤدي إلى العديد من الآثار المــدمرة تــشمل

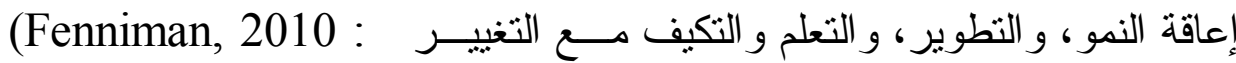

(^) (النظريات المفسرة للأمن النفسي أ - نظرية فرويد Freud في النمو النفسي الجنسي:

يشير فرويد في نظريته عن النمو إلى خمس مر احل رئيسة في النمو،

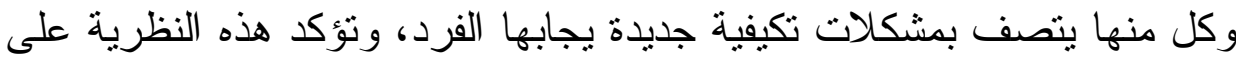

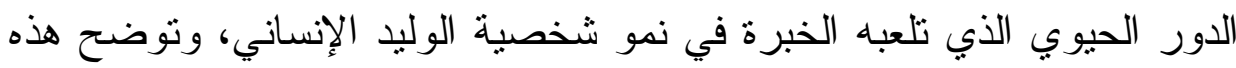

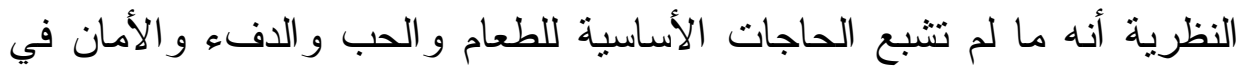

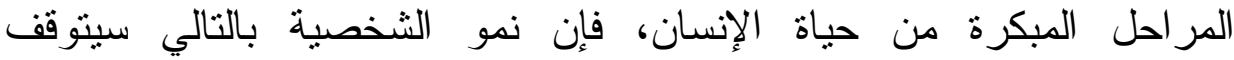

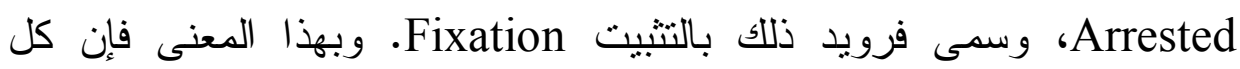
مرحلة تتكل فترة حرجة من حياة الطفل، وبدون التثبيت فإن الأطفال قد يمرون

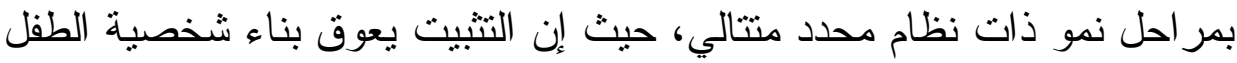

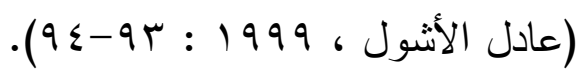

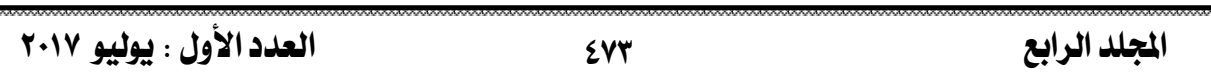


ب - نظرية إريكسون Erikson في النمو النفسي الاجتماعي:

يرى إريكسون أن الأمن النفسي و الحب و الثقة في الآخرين يقابلها حاجات

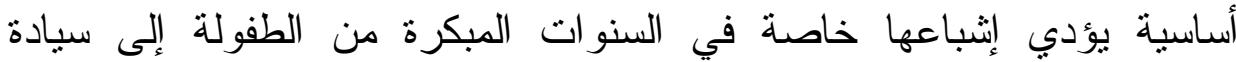
الإحساس بالطمأنينة النفسية في المراحل اللاحقة. فالمرحلة الأولى (الثقة مقابل عدم النقة) و المرحلة السادسة (الود مقابل الإنعز ال) في تصنيف إريكسون

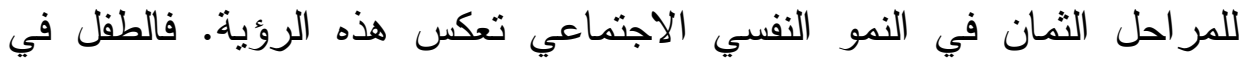

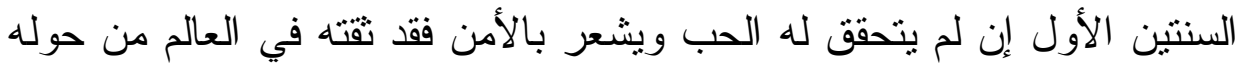

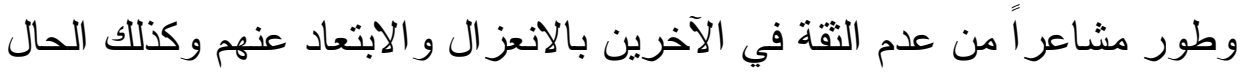

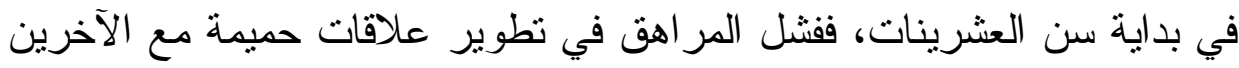

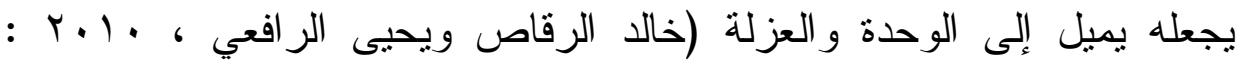

\section{ج - نظرية ماسلو Maslow في الحاجات :}

قدم ماسلو الحاجة إلى الأمن عندما وضع نظاماً هرمياً للحاجات يقوم

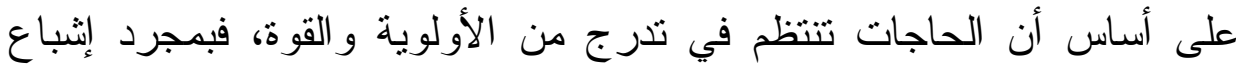

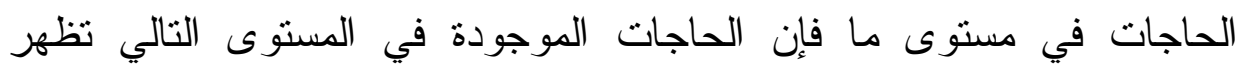

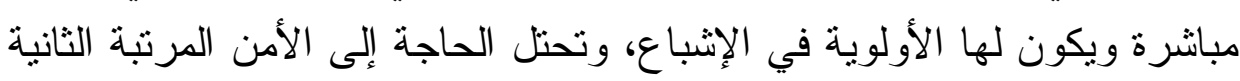

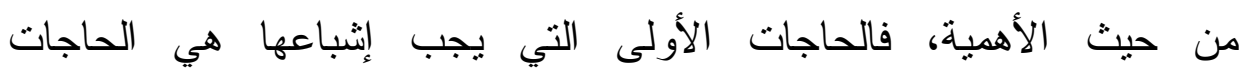

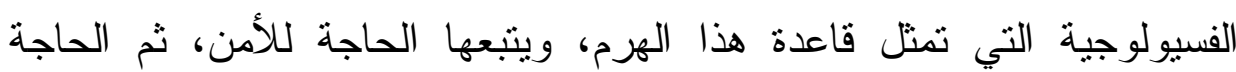

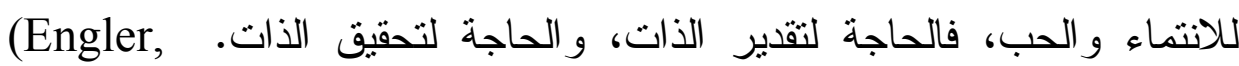

1995 : 343-344)

وتمنل الحاجة إلى الأمن أهمية كبيرة في تحقيق النمو السليم للفرد، حيث

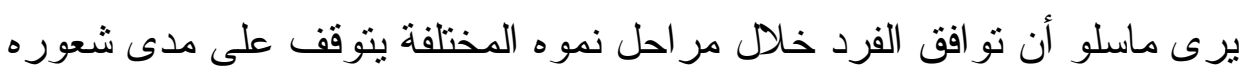
بالأمن في طفولته. ذلك أن شعور الطفل بالأمن يجعله ينتمي إلى بيئته ويتقبل 
ذاته ويكون مفهوم موجب للذات، و على العكس من ذللك فإن فقدانه للشعور بالأمن يؤدي إلى سوء نو افقه النفسي والاجتماعي. ويتحقق الثعور بالأمن في

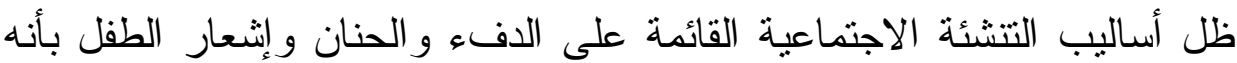

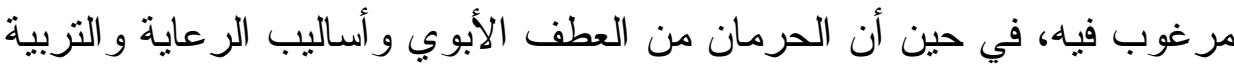

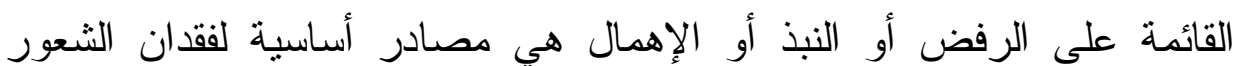

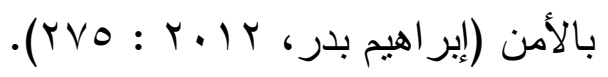
د - نظرية بولبي Bowlbey في التعلق:

لاحظ بولبي أن وعي الطفل المتز ايد خلال العامين الثاني و الثالث باقتر اب ابتعاده عن الأم يثير لديه سلوكيات التعلق متل البكاء أو الاحتجاج أو محاولة

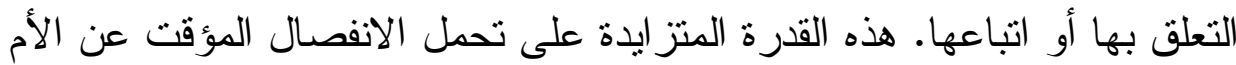
هي بالفعل قدرة الطفل على الثُعور بالأمن. وهذا على خلاف نظرية التحليل

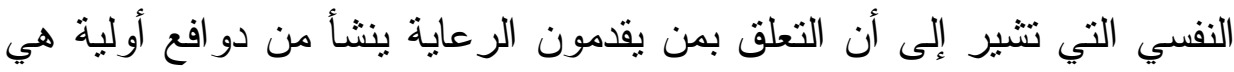

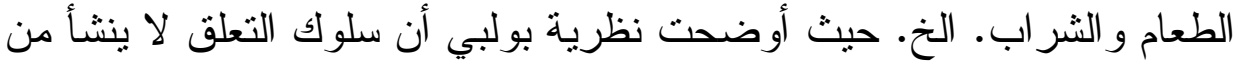

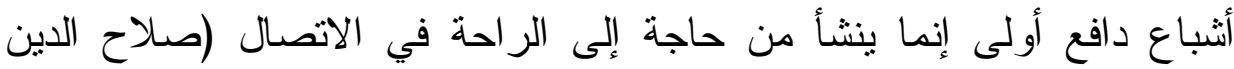

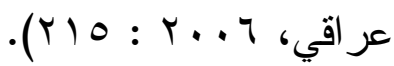

وهذا النوع من التعلق يكون بمثابة عامل للتنبؤ بنمو الثعور بالأمن حيث

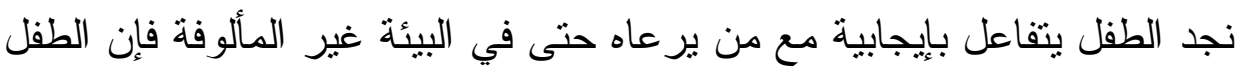

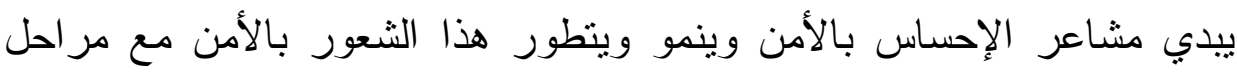

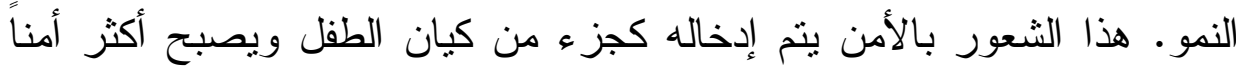

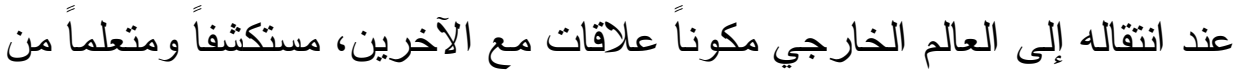
كل ما تقدمه له الحياة. حيث إن خبرات التعلق الأولى في إنتاجها للشعور بالأمن التان

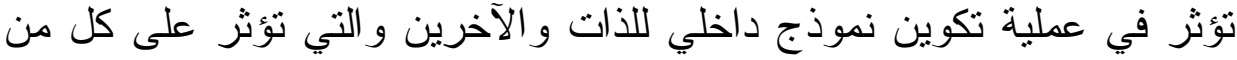

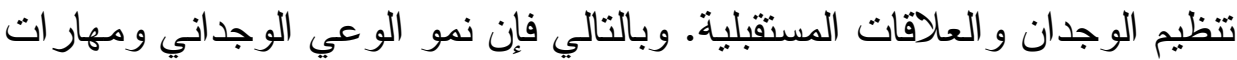

\begin{tabular}{|c|c|}
\hline العدد الأول : يوليو V|+r & EVo \\
\hline
\end{tabular}


تتظيم الوجدان اللتان تحدثان من خلال عملية التعلق تؤدي إلى الثعور بالأمن . (Lin, Enrigth \& Klatt, 2013 : 107)

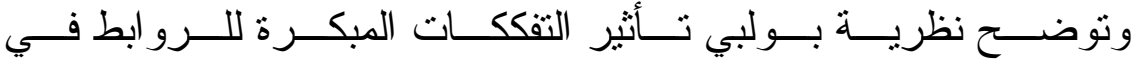
علاقات الو الدين - الطفل على نمو الوجدان وتتظيمه، فالطفل يقترب من و الديه

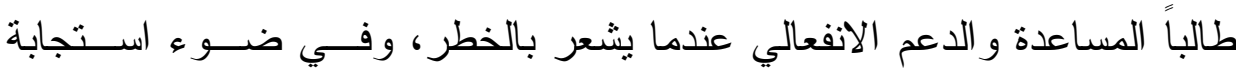

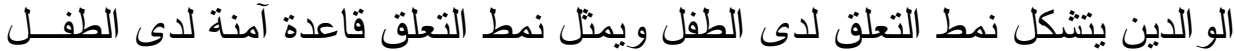

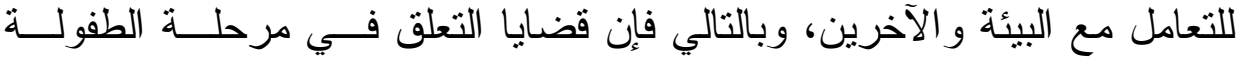

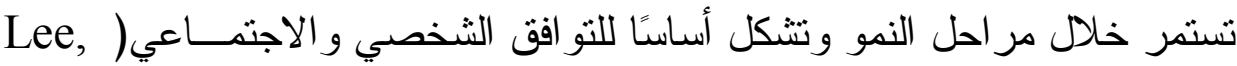
. (2013: 1500

(9) الأمن النفسي من منظور إسلامي

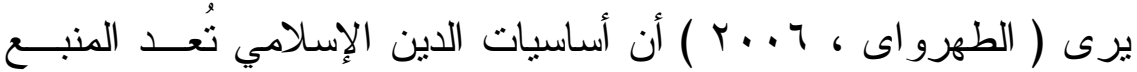

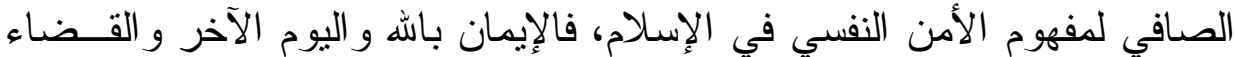

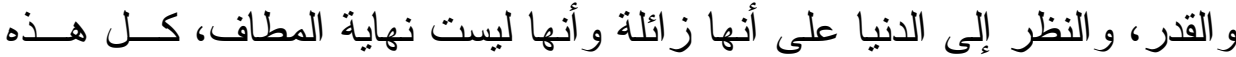

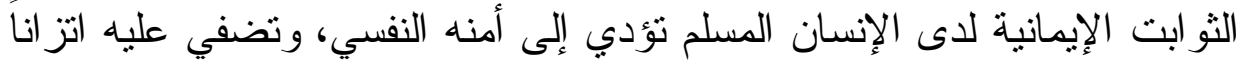

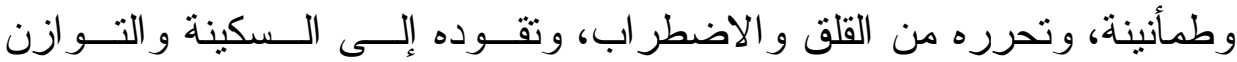

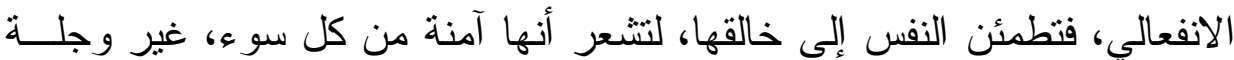

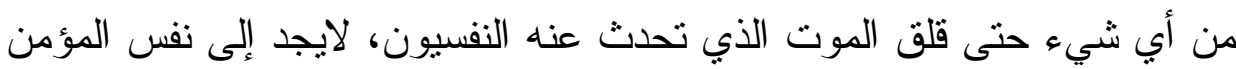
سبيلاً، فالموت يعتبر عتبة الولوج إلى باب الآخرة حيث الطمأنينة الخالدة.

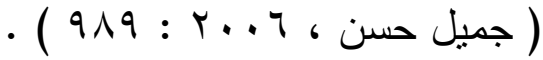

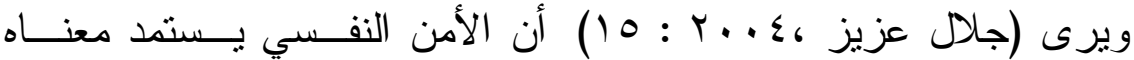

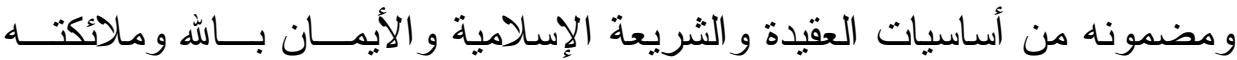

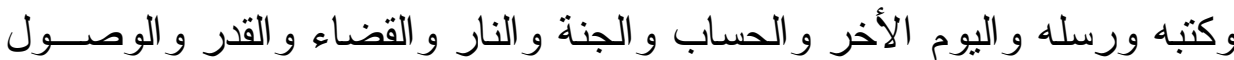

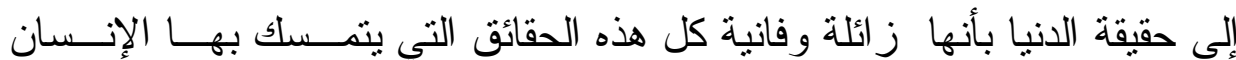

المجلد الرابع


المسلم تؤدي بـه إلى الأمن الطمأنينة وتمتعــهـ بالاســتقر ار و الـسكينة وتحــرره وتخلصه من الاضطر ابات النفسية و القلق وتقود ه إلى سكون الفكر .

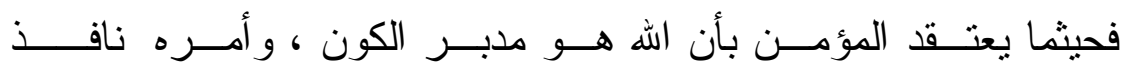

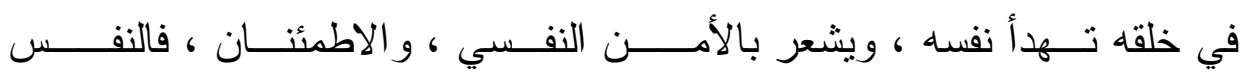

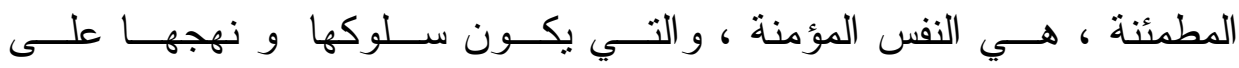

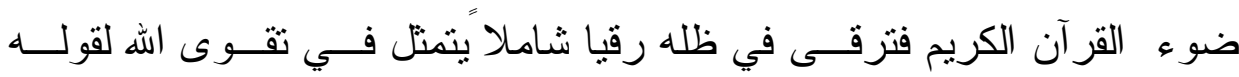

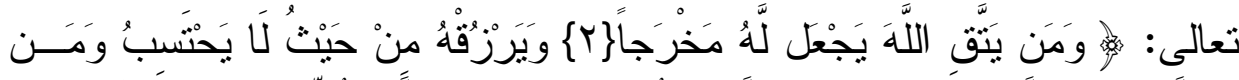

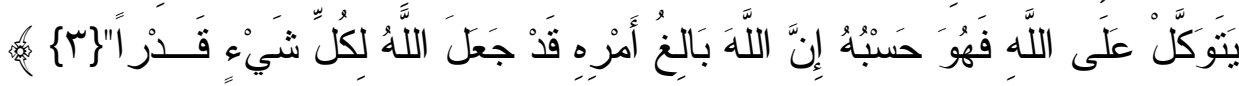

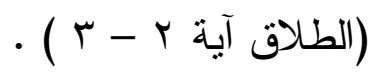

\section{وتميزت نظرة الإسلام إلى أمن الفرد والمجتمع المسلم بما يأتي:}

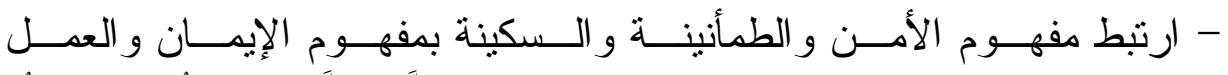

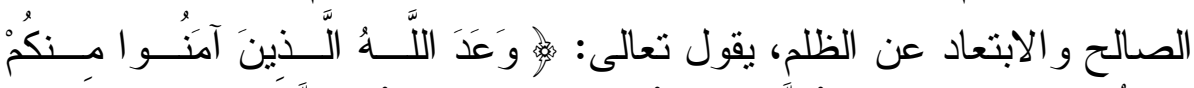

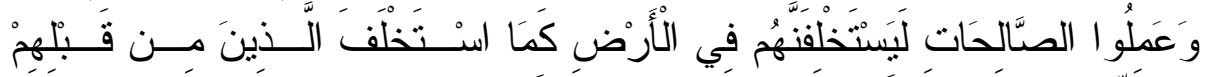

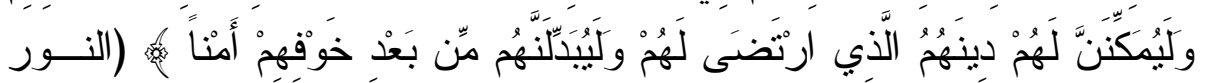

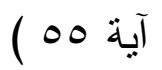

وفي موضع آخر يقول تعالى:

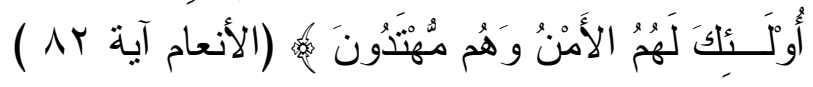

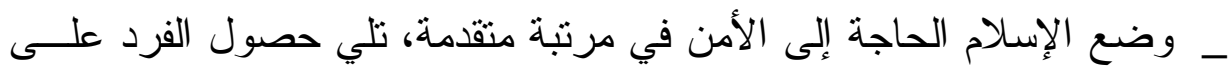

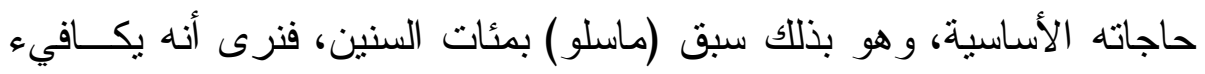
المؤمنين بإثباع حاجاتهم الأولية من مأكل ومشرب، ثم يلي ذللك تحقيق الأمن

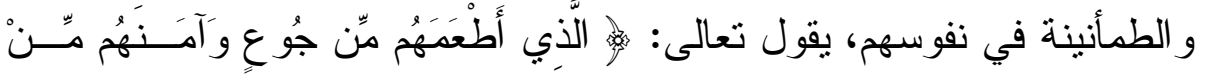

$$
\text { خَوْف }
$$


وخاطب مريم بعد ميلادها المعجز ، وتجربتها الصعبة المخيفــة بقولــهـ:

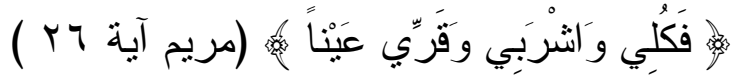

- المفهوم الإسلامي للأكن يحدد الأمن كنقيض للخوف بمـصادره المتعـددة،

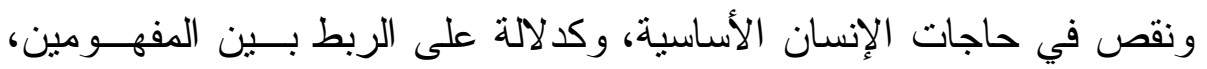

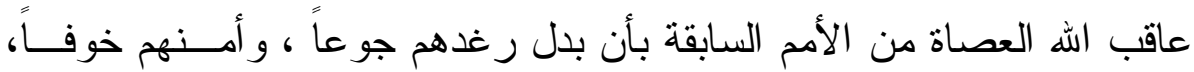

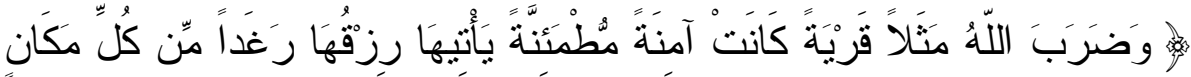

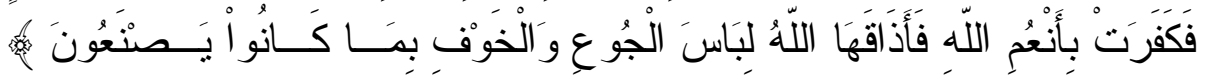

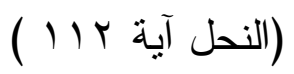

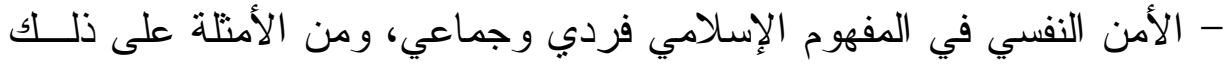
ماورد في الآيات السابقة من شو اهد في قصة مريم (أمن فردي) و القرية التي

$$
\text { كانت آمنة مطمئنة (أمن جماعي) }
$$

ـ الحاجة إلى الأمن النفسي مستمرة، استمر ار أحداث الحياة وضغوطها النفسية

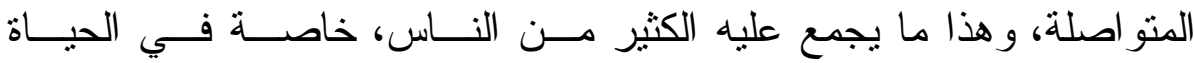

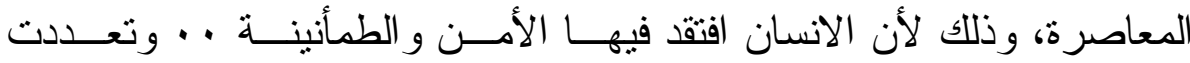

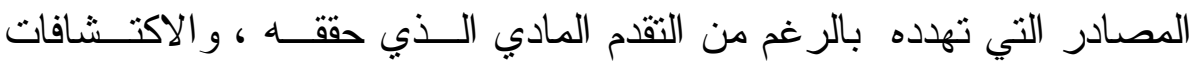

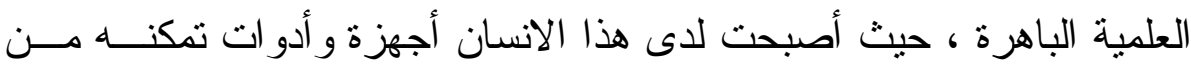

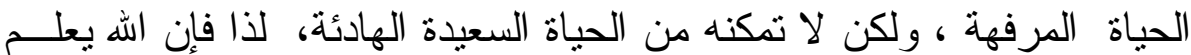

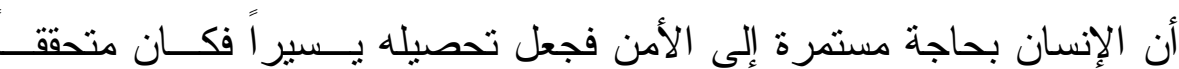

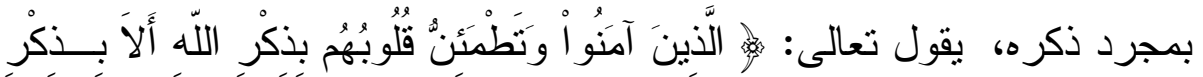

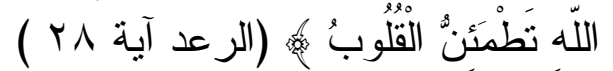

- ربط الإسلام الأمن و الطمأنينة بصالح الأعمال و السلوكيات الطيبة، ويظهـر

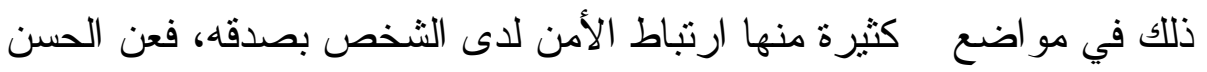

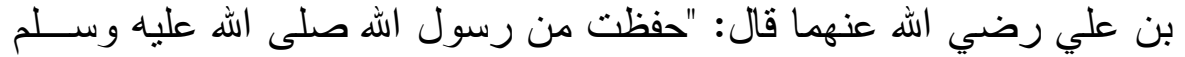


دع ما يرييك إلى ما لا يرييك فإن الصدق طمأنينة و الكذب ريبة". (محمد بـن

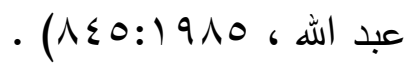

ومن السمات التي يتحقق من خلالها الأمن النفسي لاى المسلم، الرضــــا

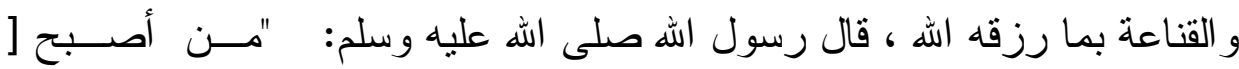

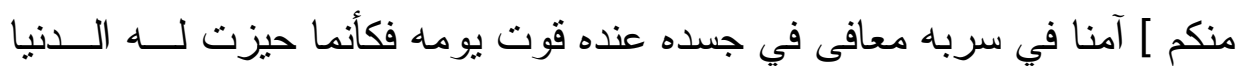

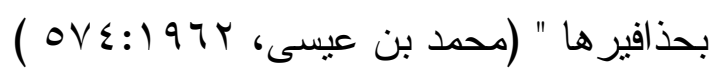

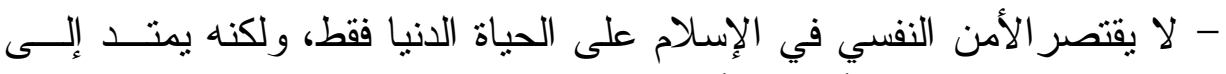

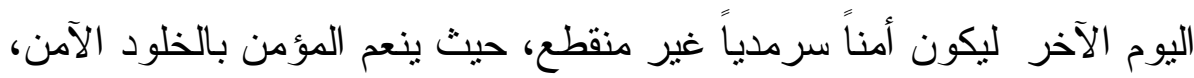

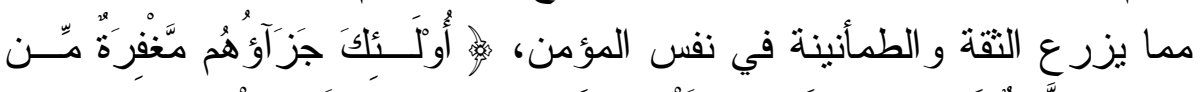

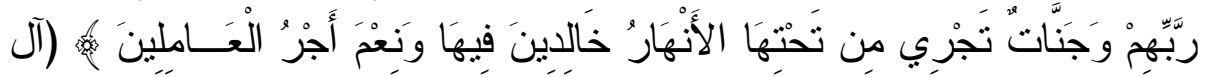

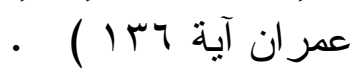

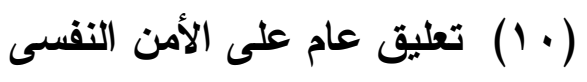

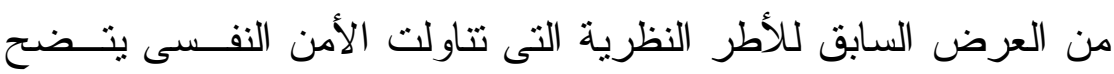

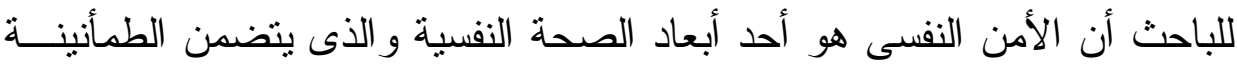

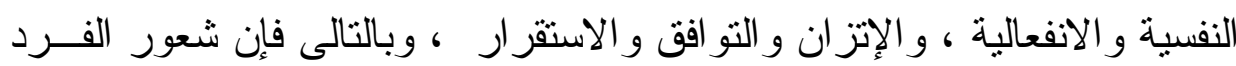

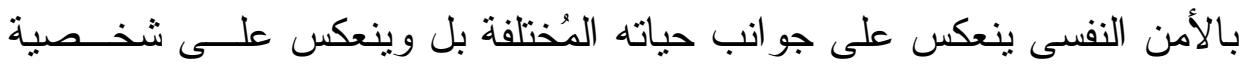

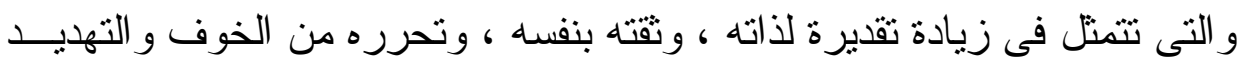

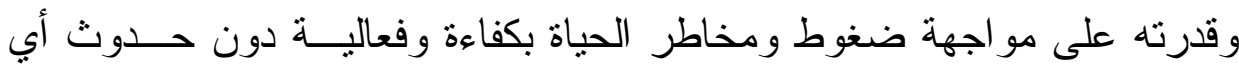

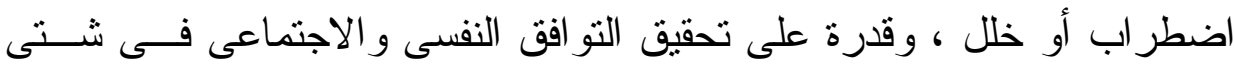

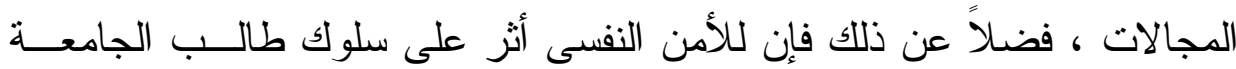

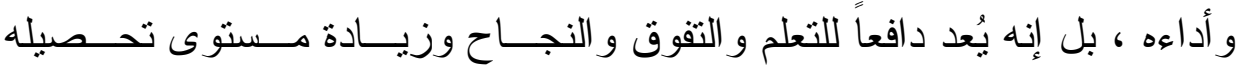

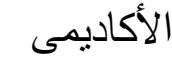




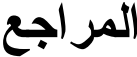

1. أحمد الخليل (1991)): الثعور بالأمن النفسي عند الطلبــة الهـــر اهقين فــي

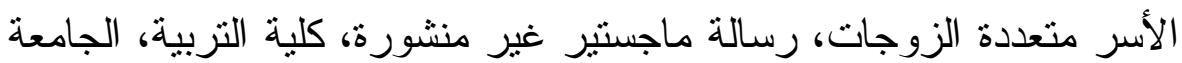

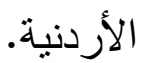

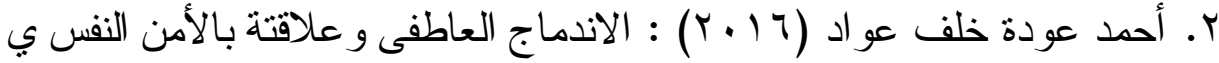

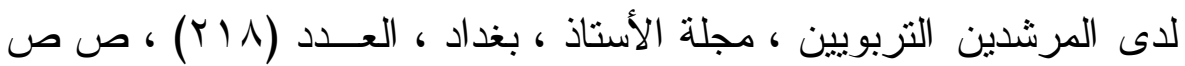
. हा $r-r \wedge q$

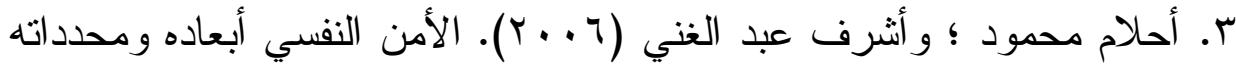

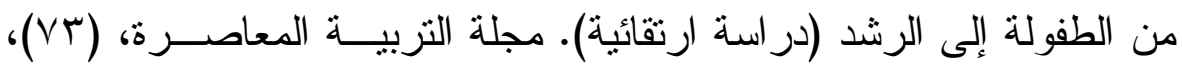
$. I V \Lambda-V V$

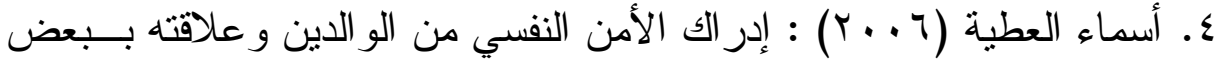

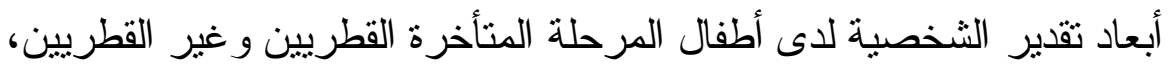
مجلة كلية التربية ، جامعة الإسكندرية .

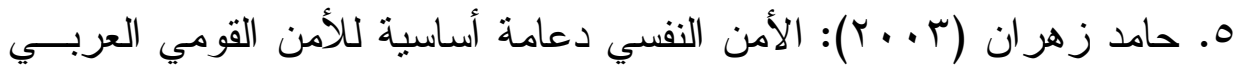

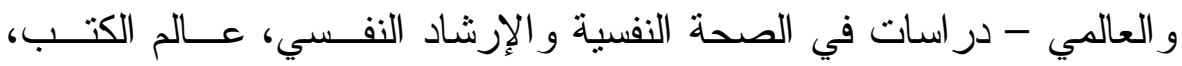

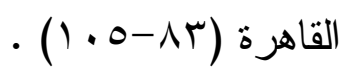

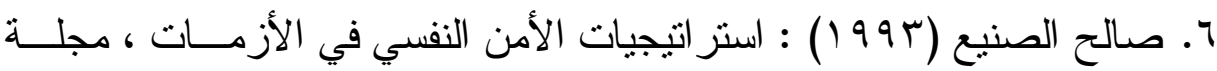
الأمن ، العدد السادس ، المملكة العربية السعودية.

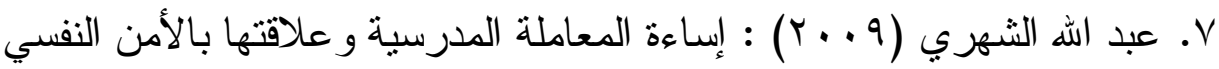
لاى عينة من تلاميذ المرحلة الابتدائية بمحافظة الطائف ، رسالة ماجستير غير منشورة، جامعة أم القرى. 


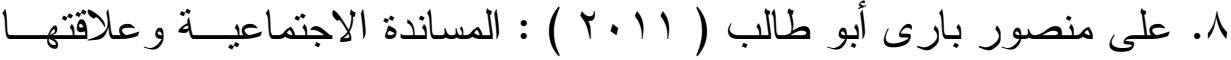
بالأمن النفسى لدى عينة من الطلاب النازحين وغير النازحين من الحسدود

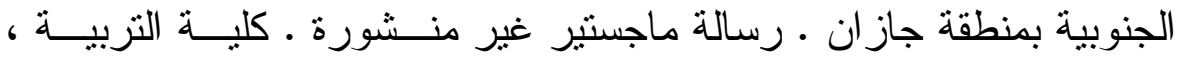

$$
\text { جامعة أم القرى • }
$$

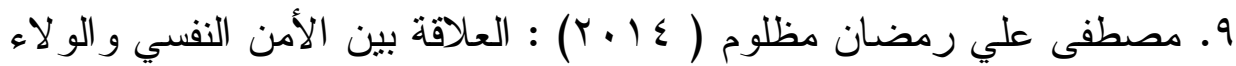

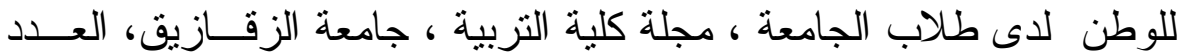

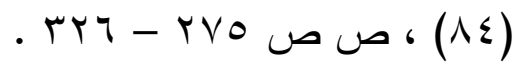

10. Abi Samra (2000). The relation between emotional intelligence and academic achievement in eleventh graders. Research in Education. Auburn University at Montgomery, Alabama, U.S.A.

11. Abtahi, Masoumeh, Sadat ; Mehrabi, Javad ; Mehdipour, Parisa \& Rahchamani, Ahmad , (2014). Invesligating the Relationship Between Emotional Intelligence and Conflict Management Case study : Empbyees of Bankrefahin Qazvin. International Journal of Current life Science . Vol.4. No.2. Pp. 315-320.

12. Al-Domi, M. M. (2012). Faith and psychological security in the Holy Quran. European Journal of Social Sciences, 32(1), 52-58.

13. Austin, E., Saklofsk, D., \&Egan, V., (2005): Personality, well-being and health correlates of trait emotional

المجلد الرابع


intelligence, personality and individual defferences, Vol.38 (3)547-558.

14. Bastian , V., Burns, N., \& Nettelbeck, T. (2005). Emotional intelligence predicts life skills, but not as well as personality and cognitive abilities. Personality and Individual Differences, Vol. 39, No. 6, Pp. 1135-1145. 